
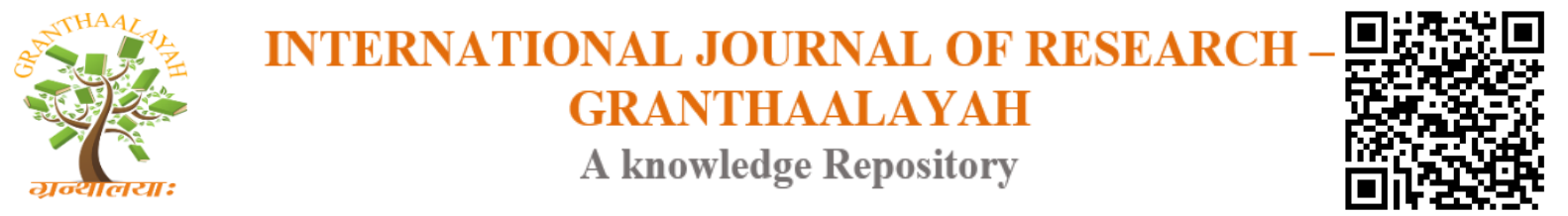

Social

\title{
IMPACT OF ENVIRONMENTAL HEALTH ON SUSTAINABLE DEVELOPMENT AMONGST RESIDENTS OF CALABAR METROPOLIS IN CROSS RIVER STATE, NIGERIA. WEST AFRICA; A CASE STUDY OF CALABAR GARMENT FACTORY
}

\author{
Bright Ewona 1, Asuquo Bassey ${ }^{2}$, Andy Ugumanim ${ }^{1}$, Mercy Ukpong 1, Dorathy Ikwen ${ }^{2}$ \\ ${ }^{1}$ Department of General Studies, College of Health Technology, Calabar, Cross River \\ ${ }^{2}$ Department of Environmental Health, College of Health Technology, Calabar, Cross River \\ State. Nigeria
}

\begin{abstract}
This research paper was geared toward unraveling the impact of environmental health on sustainable development amongst residents of Calabar metropolis in Cross River State, Nigeria, West Africa. In pursuant of this objective, three research questions were raised to guide the studyTo what extent does environmental induction course influence sustainable development among residents of Calabar metropolis? does environmental wastes recycling affect sustainable development among residence of Calabar metropolis? and to what extend does environmental conservation influence sustainable development among residents of Calabar metropolis. A sample size of 200 respondents was considered for the study. The instrument used for data collection was a 20 - items questionnaire which was validated by research experts on health discipline. Split half reliability estimate was implored to ascertain the reliability of the instrument while simple percentage was used to analyze the data collected. From the results of our findings, possible recommendations were made to ensure sustainability of our environmental resources to enhance sustainable development.
\end{abstract}

Keywords: Environmental Health; Sustainable Development; Calabar; Nigeria; West Africa.

Cite This Article: Bright Ewona, Asuquo Bassey, Andy Ugumanim, Mercy Ukpong, and Dorathy Ikwen. (2018). "IMPACT OF ENVIRONMENTAL HEALTH ON SUSTAINABLE DEVELOPMENT AMONGST RESIDENTS OF CALABAR METROPOLIS IN CROSS RIVER STATE, NIGERIA. WEST AFRICA; A CASE STUDY OF CALABAR GARMENT FACTORY." International Journal of Research - Granthaalayah, 6(11), 121-129. https://doi.org/10.29121/granthaalayah.v6.i11.2018.1095.

\section{Introduction}

Environmental health is a branch of public health that is concern with all aspects of natural and built environment that may affect human health (Obi \& Dean, 2010). 
According to world health organization (1993) environmental health comprises those aspects of human health including quality of life, that are determined by physical, chemical, biological, social and psychological factors in the environment. It can also be seen as the theory and practice of assessing, correcting, controlling and preventing factors affecting adversely the health of present and future generation. In other words, environmental health can also be referred to as environmental public health, or environmental health education (Obi and Dean, 2010).

Sustainable development refers to the development that meets the needs of the present generation without compromising the ability of future generations to meet their own needs. National Institute of Environmental Health Science $\{\mathrm{NIH}\},(2012)$. Also, Jonatan (2015) citing from ministry of the environment (2013), described sustainable development as an ongoing and structured process where society undergoes changes with the aim of securing desirable living conditions for current and future generations.

Cross River State is one out of the 36 states in Nigeria. The state is situated at the southern region of the country and makes up 18 Local Government Areas with its headquarters in Calabar. The Calabar metropolis with a population of about 371,022 according to the 2006 national population census (Simon, 2010), is both administrative and commercial hub comprising Two Local Government Areas viz, Calabar municipality and Calabar south. Companies like the flower mills, water board, gas stations, export processing zone (EPZ), Calabar sea port, the mega Calabar market, several petrol stations, countless number of eateries etc. make up the major economic activities in the metropolis. Consequent to this, Calabar metropolis presents a picture of littered environment, domestic refuge dumb, industrial wastes, air pollution, climate threat etc. and thereby posing so much threat on the life of the inhabitants of this area. Diseases like respiratory tract infections (RTIs), typhoid fever, malaria, dysentery, diarrhea etc. are occasioned in this region.

In light of the above environmental health challenges, this research work on the impact of environmental health on sustainable development among the inhabitants of Calabar metropolis becomes necessary at this time. Base on this, three pertinent research questions were necessary, they are

1) To what extend does environmental induction course influenced sustainable development among residence of Calabar metropolis

2) Does environmental wastes recycling affect sustainable development among residents of Calabar metropolis

3) To what extend does environmental conservation affect sustainable development among the inhabitants of Calabar municipality

\section{Environmental Induction Course and Sustainable Development}

Induction course are training given to people to guide them on operation and safety in the environment. World commission on environment and development \{WCED\}, (2000) refer to it as orientation given to people about all the issues concerning the environment. Induction course is a component of environmental health education. Induction course is given by environmental health educators, in most cases using the media e.g. radio, television, newspaper, handbill, poster symposiums among others. Through environmental induction course, the residents of the study area could gain awareness on the benefits of promoting and protecting the environmental life. 
Environmental health education is the process of giving awareness to individual or a group of persons on environmental protection and health promotion.

Environmental health education has brought in enlightenment, awareness, exposure, innovation and knowledge leading to scientific innovation through research. Bent and Solomon (2011) asserted that health education is the translation of what is known about health into desirable persons, individuals and commonly guiding the behavior pattern by means of education process. It can be seen as any attempt that is made to equip the people with sufficient skills or knowledge that can enable them take positive measures or actions on their own to promote personal health and that of the environment with the acquisition of healthful information that will necessitate the practical application of health knowledge, attitudes and skills.

Our consciousness for environmental sustainability begins with self-sanitation and goes down to keeping our surroundings clean through proper wastes disposal and environmental sanitation. Nwodu \& Nwabueze (2007) noted that proper environmental sanitation would ensure healthy living through the prevention of diseases like malaria, cholera, diarrhea, dysentery, and so on.

Bensons \& Juliet (2008); Okuma (2002), see induction course as a vital tool to addressing environmental problems for sustainable development. Also considering the way out of environmental malaise, Olgyaiova \& Keiski (2005) suggested that awareness campaigns should be created among residents to manage household refuse and the consequences of environmental degradation. Nwodu and Nwabueze (2007); Rim-Rukeh \& Ogbeni (2007) believe that communication plays a central role in shaping our understanding of the natural world and the role of human therein.

Some agencies in Calabar that promote environmental sustainability through induction programs are:

1) Nigerian conservation society, Calabar

2) Nigerian environmental society, Calabar

3) National environmental protection agency, Calabar

4) Department of environmental Health, College of Health Technology, Calabar

5) The Cross River State broadcasting corporation (CRBC)

6) The National television authority, NTA Calabar

7) The paradise city FM, Calabar

8) Hit FM, Calabar

9) The chronicles newspaper agency

\section{Environmental Recycling and Sustainable Development}

Recycling is a process of collecting and processing materials that would otherwise be thrown away as thrash and turning them into new product US EPA (2015). or simply put it means using raw materials that are already been extracted thereby reducing the need to extract even more to meet consumption demand. This technology has a great deal of energy even though it is yet to gain wide spread awareness especially in the rural communities. Jonatan (2015) pointed out some benefits of adopting environmental recycling measures to include the reduction of waste send to landfills, 
conservation of natural resources, reduction in pollution due to a lower need for virgin raw materials, and the possibility of creating new jobs within the recycling industry.

This technology enables us to harvest new opportunities and possibilities from what we would have ordinarily term waste. With recycling there is no spoil and no waste. Virtually everything we see, feel or touch is recyclable. Some example of recycling materials include plastics, metals, fabrics, paper, wool, sewage, water, etc. recycling process involve three steps-collecting, sorting and reuse or recovery. With the aim of gradually shifting the society from a linear economy towards a circular one, the EU setup a 4R-rule hierarchy for the reduction of waste. -ReduceReuse-Recycle-Recovery Jonatan (2015).

Going by the concept of sustainable development as cited from NIH (2012) and Jonatan (2015), sustainable development is a rather gradual process where both present and future generations have the chance of reaping in a process of time.

Although many authors example Jonatan(2015) opined that environmental recycling is a central measure to promoting and developing the environment with a wide range of benefits, others like Patz, Gibbs, Foley, Rogers \& Smith (2007) and Haines, Kovats, Campbell-Lendrum \& Corvalan (2006) feel that this practice does not totally exempt the society from the danger of pollutants released into the ecosystem by these recycling machines. Emphasizing that those by-products released into the air, land and sea as a result of industrialization, pose a lot of threat on the ecosystem. Example, the gradual depletion of the ozone layer by carbon gases from combustion, unsafe aquatic environment due to chemical pollution, and depletion of soil fertility by industrial wastes.

\section{Calabar Garment Factory}

The Calabar garment factory is at the moment a major garment recycling outfit in Calabar, the cross river state capital. It is the largest garment factory in the world by floor size. The factory is expected to reduce importation and promote local production, with an expected economic boom in the country which would also improve the growth of the gross domestic product. The garment factory is situated on a 2000 square metres land space on the Goodluck Jonathan bypass in the CRS capital. The edifice is sited on a picturesque landscape with well-pave drive way and parking lot to accommodate expected clients and staff vehicles. The factory is furnished with more than 2000 electric powered garment production machine ranging from cutting to sewing, embroidery, ironing machines and many more (Emmanuel, 2016). With a mega plant stationed to generate constant electricity for 24 hours.

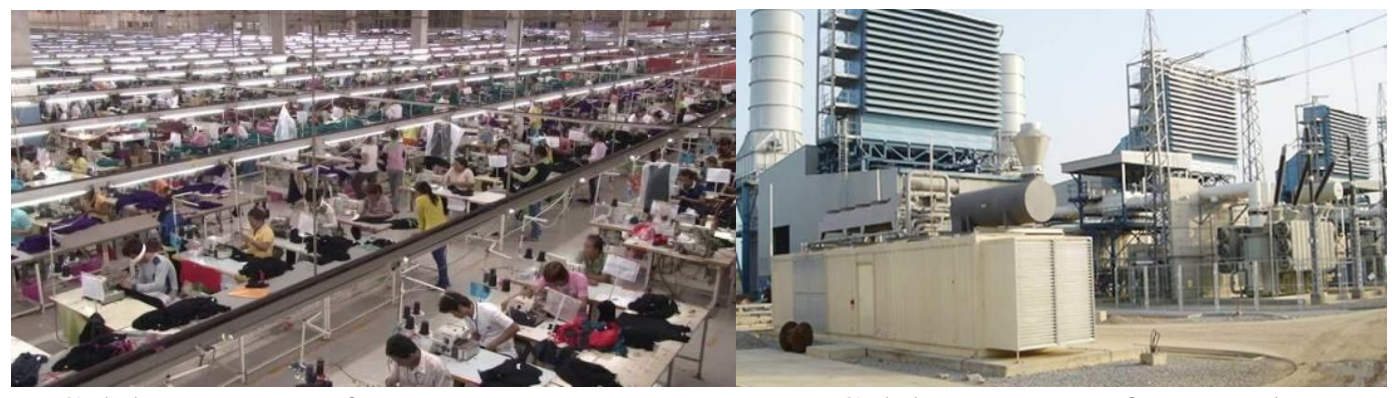

Calabar garment factory

Calabar garment factory plant 
With the above development, the Government of CRS would have to step up measures to tackle the resultant effect of environmental pollution from the numerous economic outfits and industries in the metropolis.

Economic development even if to an extent sustainable, is also accompanied by adverse environmental threats that are capable of undermining its benefits. Gregg \& John (2012) pointed out some of the benefits of improved environmental health condition to include, access to clean water, sanitation, improved sources of household energy, perinatal care, vaccination and adequate nutrition. NIH (2017) noted that these benefits are most times achieved at the expense of the environment. At the course of improving environmental health for sustainable devolpment through industrialization, we sometimes incur unintended adverse Health challenges which are mediated largely by environmental contamination, exploitation of natural resources, and poorly informed land use decisions.

Some Adverse Effects of Industrialization to the Eco-System

1) Global climate change due to fossil fuel combustion Patz JA et al (2007) and Haines A. et al (2006)

2) Exposure to air and water pollution resulting to cardiac and respiratory diseases, and other water-borne diseases

3) Impacts from greenhouse gas emission causing mental health disorders

4) Dietary changes and decrease levels of physical activities, resulting from transportation and other work and lifestyle changes, are contributing to global epidemics of obesity, diabetes, and associated diseases (NIH, 2017)

\section{Environmental Conservation and Sustainable Development}

Preservation of biological diversity, ecosystems, and natural places is critical implication to the survival of man, plants and animals. (Ecologic Development Fund, EDF, 2016). The ecosystem is constantly being threatened by man through man's unfriendly environmental activities which are capable of subjecting the environment into extinction. Man is the first threat to the ecosystem (Botanical Gardens conservation international, BGCI, 2011) and he is also the highest defaulter of conservation. When man buries his focus on economic development without relative attention to the feedback effect on the environment, he poses environmental threat and endangers nature. Our environment needs constant renewal and dressing. EDF (2016 upholds strongly to the viewpoint that, the people who live near or who are in a threatened ecosystem are the ones are best positioned to repair and protect their immediate environment.

Five ways to conserve Environmental resources for Sustainable development

1) By developing environmentally friendly practices

2) By promoting and supporting biodiversity conservation

3) By supporting sustainable development in both our locality and internationally

4) By educating the people on environmental importance

5) By recycling and reducing waste and energy consumption Peter (2009)

Some of the environmental protection agencies in Calabar are:

- The Green sheriff 
- $\quad$ The Cross River State forestry commission (forest guards)

- Calabar urban Development authority (CUDA)

- State environmental protection agency, Calabar

\section{Methodology}

The study was descriptive in approach. 200 respondents were selected from the two local governments that make up Calabar metropolis. The instrument used for data collection was $20-$ items questionnaires tagged Environmental sustainability development index questionnaire (ESDIQ). The instrument was scrutinized and tested for content validity and reliability using a spit half reliability estimate at 0.05 level of significance. The instrument was structured into four points like a scale of strongly agreed (SA). Agreed (A), disagreed (D) and strongly disagreed (SD). The scale was assigned with values of $4,3,2$, and 1 respectively for positively structured statement while reversed order was assigned for negatively structured statement. The Analysis was based on simple percentage and mean value, the items of the instrument were structured to reflect the three variables under consideration. Value with percentage higher than fifty $(50 \%)$ and mean value higher than 2.50 were considered appropriate to have exerted a significant influence on a given variable while percentages vales lower than the average was unsatisfactory in terms of influence on the environmental sustainability. The items in the instruments and the responses are structured in the table 1 below.

Table I: Esiq And the Responses $(\mathrm{N}=200)$

\begin{tabular}{|c|c|c|c|c|c|c|}
\hline $\mathbf{s} / \mathbf{n}$ & Variables/item & $\mathbf{S A}$ & $\mathbf{A}$ & D & SD & MEAN \\
\hline & Environmental induction course & & & & & \\
\hline 1 & $\begin{array}{l}\text { Awareness of our environment does not } \\
\text { ensure its sustainability }\end{array}$ & $\begin{array}{l}20 \\
10 \%\end{array}$ & $\begin{array}{l}85 \\
42.5 \%\end{array}$ & $\begin{array}{l}45 \\
22.5 \%\end{array}$ & $\begin{array}{l}50 \\
25 \%\end{array}$ & 2.65 \\
\hline 2 & $\begin{array}{l}\text { Environmental literacy program brings } \\
\text { about sustainability }\end{array}$ & $\begin{array}{l}105 \\
52.5 \%\end{array}$ & $\begin{array}{l}35 \\
17.5 \%\end{array}$ & $\begin{array}{l}25 \\
12.5 \%\end{array}$ & $\begin{array}{l}35 \\
17.5 \%\end{array}$ & 3.05 \\
\hline 3 & $\begin{array}{l}\text { Induction course enhance environmental } \\
\text { friendly practices }\end{array}$ & $\begin{array}{l}85 \\
42.5 \%\end{array}$ & $\begin{array}{l}45 \\
22.5 \%\end{array}$ & $\begin{array}{l}50 \\
25 \%\end{array}$ & $\begin{array}{l}20 \\
10 \%\end{array}$ & 2.97 \\
\hline 4 & $\begin{array}{l}\text { Hygiene and safety measures are } \\
\text { inherent factors that enhance } \\
\text { sustainability }\end{array}$ & $\begin{array}{l}107 \\
53.25 \%\end{array}$ & $\begin{array}{l}33 \\
16.5 \%\end{array}$ & $\begin{array}{l}41 \\
20.5 \%\end{array}$ & $\begin{array}{l}19 \\
9.5 \%\end{array}$ & 3.14 \\
\hline 5 & $\begin{array}{l}\text { I do not subscribe to the idea of } \\
\text { sustainability }\end{array}$ & $\begin{array}{l}75 \\
37.5 \% \\
\end{array}$ & $\begin{array}{l}25 \\
12.5 \% \\
\end{array}$ & $\begin{array}{l}59 \\
29.5 \% \\
\end{array}$ & $\begin{array}{l}41 \\
20.5 \% \\
\end{array}$ & 2.33 \\
\hline 6 & $\begin{array}{l}\text { I quest for environmental friendly } \\
\text { practice to protect our environment }\end{array}$ & $\begin{array}{l}12 \\
6 \% \\
\end{array}$ & $\begin{array}{l}95 \\
47.5 \% \\
\end{array}$ & $\begin{array}{l}83 \\
41.5 \% \\
\end{array}$ & $\begin{array}{l}10 \\
5 \% \\
\end{array}$ & 2,54 \\
\hline 7 & $\begin{array}{l}\text { Environmental Sustainability is not } \\
\text { practicable }\end{array}$ & $\begin{array}{l}0 \\
0 \%\end{array}$ & $\begin{array}{l}109 \\
54.5 \%\end{array}$ & $\begin{array}{l}51 \\
25.5 \%\end{array}$ & $\begin{array}{l}50 \\
25 \%\end{array}$ & 2.80 \\
\hline & Environmental waste recycling & & & & & \\
\hline 8 & $\begin{array}{l}\text { I am aware of recycling process of } \\
\text { wastes }\end{array}$ & $\begin{array}{l}75 \\
37.5 \%\end{array}$ & $\begin{array}{l}24 \\
12 \%\end{array}$ & $\begin{array}{l}11 \\
5.5 \%\end{array}$ & $\begin{array}{l}90 \\
45 \%\end{array}$ & 2.41 \\
\hline 9 & $\begin{array}{l}\text { Products from Recycled waste are not } \\
\text { durable and sustainable }\end{array}$ & $\begin{array}{l}39 \\
19.5 \%\end{array}$ & $\begin{array}{l}45 \\
22.5 \%\end{array}$ & $\begin{array}{l}84 \\
42 \% \\
\end{array}$ & $\begin{array}{l}32 \\
16 \% \\
\end{array}$ & 2.54 \\
\hline 10 & I like to convert waste to other products & $\begin{array}{l}58 \\
29 \%\end{array}$ & $\begin{array}{l}50 \\
25 \%\end{array}$ & $\begin{array}{l}22 \\
11 \%\end{array}$ & $\begin{array}{l}70 \\
35 \%\end{array}$ & 2.23 \\
\hline
\end{tabular}




\begin{tabular}{|c|c|c|c|c|c|c|}
\hline 11 & $\begin{array}{l}\text { Resource and machineries for recycling } \\
\text { of our waste are readily not available }\end{array}$ & $\begin{array}{l}75 \\
37.5 \%\end{array}$ & $\begin{array}{l}85 \\
42.5 \%\end{array}$ & $\begin{array}{l}14 \\
7 \%\end{array}$ & $\begin{array}{l}26 \\
13 \%\end{array}$ & 1.95 \\
\hline 13 & $\begin{array}{l}\text { The process of waste recycling is taskful } \\
\text { and costly }\end{array}$ & $\begin{array}{l}12 \\
6 \% \\
\end{array}$ & $\begin{array}{l}80 \\
40 \% \\
\end{array}$ & $\begin{array}{l}28 \\
14 \% \\
\end{array}$ & $\begin{array}{l}80 \\
40 \% \\
\end{array}$ & 2.12 \\
\hline 14 & Every recycled products are sustainable & $\begin{array}{l}117 \\
58.5 \%\end{array}$ & $\begin{array}{l}43 \\
21.5 \%\end{array}$ & $\begin{array}{ll}25 \\
12.5 \%\end{array}$ & $\begin{array}{l}15 \\
7.5 \%\end{array}$ & 3.31 \\
\hline 15 & $\begin{array}{l}\text { Recycled products lack the required } \\
\text { standard compared to the primary } \\
\text { products }\end{array}$ & $\begin{array}{l}138 \\
69 \%\end{array}$ & $\begin{array}{l}42 \\
21 \%\end{array}$ & $\begin{array}{l}18 \\
9 \%\end{array}$ & $\begin{array}{l}2 \\
1 \%\end{array}$ & 1.39 \\
\hline \multirow[t]{2}{*}{16} & $\begin{array}{l}\text { Only artificially produced material could } \\
\text { be recycled not natural products }\end{array}$ & $\begin{array}{l}45 \\
22.5 \% \\
\end{array}$ & $\begin{array}{l}49 \\
24.5 \% \\
\end{array}$ & $\begin{array}{l}56 \\
28 \% \\
\end{array}$ & $\begin{array}{l}50 \\
25 \% \\
\end{array}$ & 2.55 \\
\hline & Environmental conservation & & & & & \\
\hline 17 & $\begin{array}{c}\text { I am aware of environmental } \\
\text { conservation practices }\end{array}$ & $\begin{array}{l}92 \\
46 \%\end{array}$ & $\begin{array}{ll}28 \\
14 \%\end{array}$ & $\begin{array}{l}60 \\
30 \% \\
\end{array}$ & $\begin{array}{ll}20 \\
10 \%\end{array}$ & 2.96 \\
\hline 18 & $\begin{array}{l}\text { Conservation is keyed in environmental } \\
\text { sustainability }\end{array}$ & $\begin{array}{l}80 \\
40 \%\end{array}$ & $\begin{array}{l}32 \\
16 \%\end{array}$ & $\begin{array}{l}18 \\
9 \%\end{array}$ & $\begin{array}{l}70 \\
45 \%\end{array}$ & 2.61 \\
\hline 19 & $\begin{array}{l}\text { Environmental conservation enhance } \\
\text { waste management }\end{array}$ & $\begin{array}{l}100 \\
50 \%\end{array}$ & $\begin{array}{l}49 \\
24.5 \%\end{array}$ & $\begin{array}{l}16 \\
8 \%\end{array}$ & $\begin{array}{l}35 \\
17.5 \%\end{array}$ & 3.07 \\
\hline 20 & $\begin{array}{l}\text { I do not believe on conservation as a way } \\
\text { forward for sustainability }\end{array}$ & $\begin{array}{l}101 \\
50.5 \%\end{array}$ & $\begin{array}{l}35 \\
17.5 \% \\
\end{array}$ & $\begin{array}{l}44 \\
22 \%\end{array}$ & $\begin{array}{ll}20 \\
10 \% \\
\end{array}$ & 1.96 \\
\hline
\end{tabular}

\section{Discussion of Result}

The data analysis was based on simple percentages and mean value obtained in each item in the instrument. Table 1 above shows the item by item distribution and the respective values. The average mean value of 2.50 was considered as a reference mean based on either positively or negatively structured statement in each item. The percentage value of $50 \%$ was equally considered for reference. thus, the values above the reference mean of 2.50 and 50th percentile was considered to have exerted a greater influence on the variable while values below the reference mean of 2.50 was said to have less significance influence on the variable under consideration. In research question 1- Induction Course does not significantly influence environmental sustainability. It was found that most items have mean values significantly above the reference mean of 2.50. This implies that, induction course help in creating awareness and is very instrumental to sustainability of our environment. This result agrees with the assertion of Bensons \& Juliet (2008) who see environmental induction course as a vital tool to addressing environmental problems for sustainable development. Again, the indices of the findings are in line with the position of Olgyaiova \& Keiski (2005) who suggested that environmental health awareness campaigns should be created among residents.

Research Question 2- To what extent does environmental Recycling of waste influence sustainable development. Here the indices of the finding revealed that the mean value and percentages calculated were remarkably above average. The implication here is that, recycling of waste enhances sustainability. This result is in tandem with the position of Jonatan (2015) that environmental recycling is a central measure to promoting and developing the environment with a wide range of benefits. However, the findings are contrary to the findings of Patz et al (2007) and Haines et al (2006) that industrialization has a negative impact on sustainable Development. This 
assertion is akin to the view point of NIH (2017) that recycling process of waste enhances industrialization which hitherto does not encourage sustainable development.

In research question 3- to what extent does environmental conservation influence sustainable development., the analysis revealed that the mean value of 2.5 was exceeded. It implies that conservation is sin qua non to sustainability. The results tend to conform to the findings of the EDF (2015) that conservation of the ecosystem is critical for sustainable development. The result also corroborated with the assertion of BGCI (2011) on the importance of conservation on Sustainable Development.

\section{Conclusion}

In conclusion, the results led credence to the fact that, induction course, waste recycling and conservation practices are inherent environmental protection/ promotion measures that enhance environmental health impact and assessment for sustainable development among residence of Calabar metropolis.

\section{Recommendations}

1) The Government should introduce environmental health induction courses through improved environmental awareness programs to enable the inhabitants see environmental impact assessment as a vital component of health for sustainable development. This can be best achieved through the media, formal education, seminars and symposia etc.

2) The government should set up recycling industries in the state to improve waste management activities and reduce the level of pollution and ecosystem hazard from industrial and market wastes

3) Environmental education should not only be a literacy program. The uneducated in the society should also be made to know the full benefits of environmental promotion. To achieve this feat, the Government should incorporate environmental health education into the secondary school curriculum and introduce house-to-house awareness campaigns

4) The state legislature should make environmental friendly laws that would check incessant exploitation of environmental resources by inhabitants. These laws can be effectively enforced by the environmental laws enforcement agencies.

\section{References}

[1] Bent, B. and Solomon, J. (2011). Impact of electronic media in sustainable waste management. Rome: IUCP press

[2] Benson, U. and Juliet, D. (2008). National resources and resources and future generation in Nigeria. Abuja: Udemsco press.

[3] Botanical Gardens conservation international $\{\mathrm{bGCI}\}$ (2011): the challenge of sustainability for botanic gardens. www.bgci.org/plant-consrevation

[4] Ecologic Development Fund empowers, EDF (2016). EcoLogic Development Fund empowers rural and indigenous peoples to restore and protect tropical ecosystems in Central America and Mexico. (617) 441-6300 |info@ecologic.org

[5] Emmanuel E. (2016): Cross River garment factory and Dr. Frank Ayade. Separating truth from outright lies 
[6] Gregg L. F. and John B. (2012). Global environmental health and sustainable development: the role at Rio+20. National Institute of Environmental Health Sciences. john.balbus@nih.gov

[7] Haines A, Kovats R, Campbell-Lendrum D, Corvalan C. (2006). Climate change and human health: impacts, vulnerability, and mitigation. The Lancet. 367(9528):2101-9.

[8] Jonatan A. (2015). Recycling and sustainable practices in the plastic industry. Environmental engineering. Bachelor thesis

[9] National institute of environmental health sciences, NIH (2017). Global environmental health and sustainable development. - U.S. Department of Health and Human Services.111 T.W. Alexander Drive Durham,N.C. 27709

[10] Nwodu, A. and Nwabueze, K. (2007). Impact of media on solid waste generation umuohia: jonathan press

[11] Obi, A. and Dean, T. (2010). Education for sustainable development; new york: universal press

[12] Olgyaiova, D. and Kieski, Y. (2005). The concept of environmental awareness in Nigeria. Abuja: macmillan press.

[13] Okuma, P. A. (2002). The concept of sustainable society. Church hill: living stone press.

[14] Patz JA, Gibbs HK, Foley JA, Rogers JV, Smith KR. (2007) Climate Change and Global Health: Quantifying a Growing Ethical Crisis. EcoHealth. 4(4):397-405.

[15] Peter W. J. (2009). developing botanic garden policies and practices for environmental sustainability. BGjournal vol.6(2)03-06

[16] Rim-Rubek, J. and Ogebeni, O. (2007). Communication facilities and attitude change. Port Harcourt: academic press

[17] Simon O. E (2010). The population in Cross River State of Nigeria and its implication for socioeconomic development from the 1991 census. www.dailytrust.com jul.26

[18] USEPA. (2015). United states environmental protection agency. http:www.epa.gov/recyclingbasics

[19] World commission on environment and development UNCED (1992). Environment and health. Edinburg: university of Edinburg

[20] World health organization WHO (1993). Concept of environmental health. Geneva: HC press.

\footnotetext{
*Corresponding author.

E-mail address: bewona@ yahoo.com
} 